\title{
The Association Between Vitamin D and Acute Rejection in Human Kidney Transplantation: A Systematic Review and Meta-analysis Study
}

Mohammad Mirzakhani

Babol University of Medical Sciences

Sheyda Mohammadkhani

Babol University of Medical Sciences

Shirin Hekmatirad

Babol University of Medical Sciences

Soudabeh Aghapour

Babol University of Medical Sciences

Negar Gorjizadeh

Kharazmi University

Mehdi Shahbazi

Babol University of Medical Sciences

Mousa Mohammadnia-Afrouzi ( $\sim$ m.mohammadnia@mubabol.ac.ir)

Babol University of Medical Sciences

Research Article

Keywords: kidney transplantation, vitamin D, 25-hydroxyvitamin D, 1,25-dihydroxyvitamin D, acute rejection, inflammation

Posted Date: January 23rd, 2021

DOI: https://doi.org/10.21203/rs.3.rs-133926/v2

License: () (1) This work is licensed under a Creative Commons Attribution 4.0 International License. Read Full License 


\section{Abstract}

Background: Vitamin D (VitD) deficiency is associated with several diseases such as multiple sclerosis, rheumatoid arthritis, respiratory infection, and so forth. In the field of transplantation (kidney transplantation), some studies reported that patients with VitD deficiency are of increased chance of acute rejection, but other studies did not show such a chance. On the other hand, since VitD is a modulatory factor and can reduce the inflammatory response, understanding the exact role of it in transplantation may contribute to tolerance condition in these patients.

Methods: The electronic databases, including PubMed, Scopus, Embase, ProQuest, Web of Science, and Google Scholar, were searched for eligible studies. In general, 14 studies with a total of 4,770 patients were included in this meta-analysis. Regarding the methodological heterogeneity, we selected a random-effects combination model. Moreover, $O R$ was chosen as an effect size for this study.

Results: After the combination of 14 studies, we showed that patients in the VitD-deficient group had an $82 \%$ increased chance of acute rejection compared with patients in the VitD-sufficient group, and this effect was significant (OR 1.82; $95 \%$ confidence interval [Cl] [1.29, 2.56]; $P=52.3 \%)$. This result was significant, and, regarding the narrow $\mathrm{Cl}$, it can be a conclusive result. Study quality and gender variables were the main sources of inconsistent results in the primary studies. Moreover, using meta-regression, we showed that VitD deficiency (independent from the estimated glomerular filtration rate (eGFR) of patients) increased the chance of acute rejection.

Conclusion: The normal VitD status of patients a few days before and after transplantation can reduce the risk of acute rejection, as it has definite modulatory effects on immune cells.

\section{Introduction}

Vitamin D (VitD) is a fat-soluble steroid, which participates in bone health through regulating the calcium and phosphate metabolism. VitD is produced after skin exposure to ultraviolet solar irradiation or can be acquired in the diet or vitamin supplements. Cholecalciferol (D3) and ergocalciferol (D2) are two main sources of VitD, which needs two steps of hydroxylation to become biologically active. After the first hydroxylation, which is performed in the liver, the D2 and D3 are converted to 25-hydroxyvitamin D. It is the main type of VitD in the circulation with a half-life of 2-3 weeks and is routinely measured to determine the VitD status. The second hydroxylation is performed in the kidney through cytochrome P450 1-a hydroxylase enzyme CYP27B1, leading to the production of the active form of VitD, i.e., 1,25-dihydroxyvitamin D (1-4).

VitD is a crucial factor for the immune system, as its receptor is expressed on monocytes, macrophages, dendritic cells (DCs), and activated lymphocytes. 25-hydroxyvitamin $D$ can bind to its receptor on mentioned immune cells and be converted to 1,25-dihydroxyvitamin $D$. Then, 1,25dihydroxyvitamin $D$ increases the production of antimicrobial peptides, such as cathelicidin and defensin $(3,5-7)$.

In contrast, the effect of VitD on DCs and T/B lymphocytes is regulatory. DCs and T/B lymphocytes are the major immune cells, initiating the immune responses of the recipient against the allograft (3). The VitD reduces the inflammatory cytokines of Thelper 1 (TH1) and TH17 and increases the antiinflammatory cytokines of TH2 and regulatory T cells (Tregs). Moreover, VitD reduces the proliferation, immunoglobulin $\mathrm{G}(\mathrm{IgG})$, and immunoglobulin M (IgM) of B lymphocytes $(3,6,8-11)$. Another important regulatory effect of VitD is on DCs. DCs are very crucial cells to initiate and stimulate T cells against the allograft. VitD could reduce the antigen presentation capacity of DCs by reducing the major histocompatibility class II (MHCII) and costimulatory molecules. These regulatory effects of VitD on the immune system may contribute to a better function of allograft and reduce the risk of allograft rejection $(3,12,13)$.

VitD deficiency $($ VitD $<20 \mathrm{ng} / \mathrm{ml})(14)$ is associated with several immune and non-immune diseases and disorders, including multiple sclerosis, rheumatoid arthritis, respiratory infection (3), cystic fibrosis (15), cardiovascular (16), and hematological diseases (17). Moreover, in the field of transplantation (kidney transplantation), some studies reported that VitD deficiency remarkably increases the risk of acute rejection $(18,19)$, while others did not indicate such a risk $(20,21)$. Since VitD deficiency is more common in the kidney transplant recipients compared with the general population $(19,22)$, and there is no consistency regarding the association between VitD concentrations and acute rejection, we aimed to carry out the first systematic review and meta-analysis to clarify whether VitD-deficient patients are more susceptible to acute rejection.

\section{Methods}

\subsection{Protocol and Registration}

This systematic review and meta-analysis study was prospectively registered with the National Institute for Health Research (PROSPERO: CRD42020216086). We followed the Reporting Checklist for Meta-analyses of Observational Studies (MOOSE) (23) and Preferred Reporting Items for Systematic Reviews and Meta-analyses (PRISMA) (24) statements to report this study (Supplemental File 1.1).

\subsection{Eligibility Criteria}

\subsubsection{Type of Study}


All observational studies (such as cross-sectional, case-control, and cohort), as well as interventional studies (randomized or non-randomized), were included in this study. In contrast, case-report, case-series, narrative reviews, animal studies, and letters were excluded.

\subsubsection{Type of Participants}

Kidney transplant recipients with and without acute rejection were enrolled in this study, which their pre- or post-transplant 25-hydroxyvitamin D levels were assessed. Recipients features are as follows: (i) biopsy-proven or clinically suspected acute rejection, (ii) received living or deceased donor kidney transplant, (iii) received their transplant for the first time or more, (iv) have experienced acute rejection up to 12 months after transplantation, and (v) with any age and gender. We excluded studies that did not separate the acute and chronic rejected patients and that measured 1,25-dihydroxyvitamin D instead of 25-hydroxyvitamin D.

\subsubsection{Outcome}

The outcome is the occurrence of acute rejection in kidney transplant recipients. Acute rejection is any type of cell-mediated or antibody-mediated rejection with any score or grade.

\subsection{Search Strategy}

The electronic databases searched by authors were PubMed, Scopus, Embase, ProQuest, Web of Science, and Google Scholar. Moreover, the gray literature (conferences/congress papers and theses) and reference lists of included studies were searched. The primary studies are from 1 January 1990 up to 31 October 2020. We used the keywords "kidney transplantation," "acute rejection," "25-hydroxyvitamin D," and their synonym for the search syntax. The Medical Subject Headings (MeSH) and free-text method were used to create search syntax. The search syntax of the PubMed database is shown in Supplemental File 1.

\subsection{Study Selection}

The records searched in all databases were exported to the EndNote software, and duplicated records were removed. Authors performed the screening process using titles and abstracts. Then, two reviewers independently read the full text of screened papers and selected those that had the main data for conducting meta-analysis. Any disagreement was resolved by consensus.

\subsection{Risk of Bias Assessment}

The quality assessment of included studies was independently done by two reviewers using the Newcastle-Ottawa Quality Assessment Scale (NOS) for observational studies (25). Moreover, the quality of a trial study was assessed using the Cochrane checklist (26). The modified version of NOS checklists for observational studies are shown in Supplemental File 2.

\subsection{Data Extraction}

Two reviewers independently extracted data from included studies using a data extraction form as follows: first author name, publication year, maintenance therapy, induction therapy (IT), donor type (living vs. deceased), estimated glomerular filtration rate (eGFR), and age and gender of study subjects. Any disagreement was resolved by consensus, and, for incomplete data, we contacted the corresponding authors of the studies.

\subsection{Data Synthesis and Analyses}

The main data for conducting the meta-analysis are as follows (i.e., four numbers): the numbers of non-acute and acute rejection patients in the VitDdeficient (VitD $<20 \mathrm{ng} / \mathrm{ml}$ ) group and the numbers of non-acute and acute rejection patients in the VitD-sufficient (VitD $\geq 20 \mathrm{ng} / \mathrm{ml}) \mathrm{group}$. We used the term "sufficient" for VitD $\geq 20 \mathrm{ng} / \mathrm{ml}$ patients in the whole manuscript and figures. According to the type of included studies and main data for performing the meta-analysis, we employed $O R$ as an effect size to be reported in this study. According to the methodological heterogeneity between included studies, we selected a random-effects model as an appropriate combination model (27). The pooled effect size was plotted using a forest plot.

Statistical heterogeneity between included studies was evaluated using the $R$ index (28). The severe statistical heterogeneity was considered $R>50 \%$.

\subsection{Publication Bias Assessment}

We used three methods to assess publication bias as follows: the funnel plot (which is the visual assessment of publication bias), Begg's (29) and Egger's (30) tests (whish statistically assess publication bias), and trim and fill method (which assesses probable missing papers) (31).

\subsection{Additional Analyses}

\subsubsection{Subgroup Analyses}

We performed some subgroup analyses to find out potential sources of statistical heterogeneity observed between included studies. The other purpose of subgroup analyses was to know whether the pooled effect size was influenced by different variables in each subgroup analysis.

Subgroup analyses were performed as follows:

Quality of Studies 
Studies with high quality (i.e., $\geq 6$ ) were compared with those with low quality (i.e., $<6$ ).

Induction Therapy

Studies with induction therapy (IT) were compared with those without IT.

Age

Studies with patients $\leq 47$ years were compared with those with patients $>47$ years in each group (VitD $<20 \mathrm{ng} / \mathrm{ml}$ and VitD $\geq 20 \mathrm{ng} / \mathrm{ml})$ separately.

Gender

Studies with more male patients were compared with those with fewer male patients.

Donor Type

Studies with living donor more than $50 \%$ were compared with those with living donor less than $50 \%$ in each group (VitD $<20 \mathrm{ng} / \mathrm{ml}$ and VitD $\geq 20$ $\mathrm{ng} / \mathrm{ml}$ ) separately.

\subsubsection{Meta-Regression Analysis}

Regarding the low number of studies that reported the eGFR of their patients, we decided to do meta-regression to evaluate whether eGFR affect the pooled effect size.

\subsubsection{Sensitivity Analysis}

We utilized the one-out-remove method to do sensitivity analysis. In this method, the pooled effect size was recalculated after removing the effect of each study. This method was used to know whether there was any difference between the results after removing a study. If yes, how much does the recalculated pooled effect size change?

This study was analyzed using STATA Version 13 (StataCorp, College Station, TX, USA).

\section{Results}

\subsection{Study Selection}

After searching the electronic databases, we identified a total of 9,398 records. Literature search procedure is shown in Fig. 1 . After screening the records according to the title and abstract, 924 records remained, and, after removing duplicated records, 766 records remained. After full-text assessment of 766 records, 14 records included in the meta-analysis. Finally, we included 14 studies $(18-22,32-40)$ with a total of 4,770 kidney transplant recipients in this systematic review and meta-analysis.

\subsection{Study Characteristics}

Studies included in this meta-analysis are from 2005 to 2020 . Among 14 included studies, 10 studies were cohort studies, three were cross-sectional, and one was a randomized clinical trial (RCT). Eleven studies reported the patients' characteristics in two groups (i.e., VitD-deficient and -sufficient groups), while three studies did not. These studies reported several variables including immunosuppressive agents (14 studies), age (11 studies), gender (11 studies), donor type (10 studies), and eGFR (nine studies) (see Table 1). Moreover, the quality of all 14 included studies is reported in Supplemental File 3. 
Table 1

Characteristics of 14 included studies.

\begin{tabular}{|c|c|c|c|c|c|c|c|c|c|c|c|}
\hline ID & $\begin{array}{l}\text { Author } \\
\text { (Year) }\end{array}$ & $\begin{array}{l}\text { Study } \\
\text { type }\end{array}$ & $\begin{array}{l}\text { Study } \\
\text { quality }\end{array}$ & $\begin{array}{l}\text { Immunosuppressive } \\
\text { agents }\end{array}$ & $\mathrm{Age}^{1}$ & $\mathrm{Age}^{2}$ & Gender $^{1}$ & Gender $^{2}$ & $\begin{array}{l}\text { Donor } \\
\text { type }\end{array}$ & eGFR $^{1}$ & eGFR ${ }^{2}$ \\
\hline 1 & $\begin{array}{l}\text { Park et al. } \\
\text { (2017) }\end{array}$ & Cohort & High & $\begin{array}{l}\text { Triple therapy plus } \\
\text { IT }\end{array}$ & $\leq 47$ & $>47$ & $\begin{array}{l}\text { With } \\
\text { more } \\
\text { male } \\
\text { patients }\end{array}$ & $\begin{array}{l}\text { With } \\
\text { more } \\
\text { male } \\
\text { patients }\end{array}$ & $\begin{array}{l}\text { Both } \\
\text { living } \\
\text { and } \\
\text { deceased } \\
\text { donors }\end{array}$ & $\begin{array}{l}63 \\
\mathrm{ml} / \mathrm{min} / 1.73 \\
\mathrm{~m} 2\end{array}$ & $\begin{array}{l}60 \\
\mathrm{ml} / \mathrm{min} / 1.73 \\
\mathrm{~m} 2\end{array}$ \\
\hline 2 & $\begin{array}{l}\text { Kulshrestha } \\
\text { et al. } \\
\text { (2013) }\end{array}$ & Cohort & Low & Triple therapy & $>47$ & $\leq 47$ & $\begin{array}{l}\text { With } \\
\text { more } \\
\text { male } \\
\text { patients }\end{array}$ & $\begin{array}{l}\text { With } \\
\text { fewer } \\
\text { male } \\
\text { patients }\end{array}$ & $\begin{array}{l}\text { Both } \\
\text { living } \\
\text { and } \\
\text { deceased } \\
\text { donors }\end{array}$ & $\begin{array}{l}54 \\
\mathrm{ml} / \mathrm{min} / 1.73 \\
\mathrm{~m} 2\end{array}$ & $\begin{array}{l}57 \\
\mathrm{ml} / \mathrm{min} / 1.73 \\
\mathrm{~m} 2\end{array}$ \\
\hline 3 & $\begin{array}{l}\text { Lee et al. } \\
\text { (2014) }\end{array}$ & Cohort & High & $\begin{array}{l}\text { Triple therapy plus } \\
\text { IT }\end{array}$ & $>47$ & $>47$ & $\begin{array}{l}\text { With } \\
\text { fewer } \\
\text { male } \\
\text { patients }\end{array}$ & $\begin{array}{l}\text { With } \\
\text { more } \\
\text { male } \\
\text { patients }\end{array}$ & $\begin{array}{l}\text { Both } \\
\text { living } \\
\text { and } \\
\text { deceased } \\
\text { donors }\end{array}$ & $\begin{array}{l}40 \\
\mathrm{ml} / \mathrm{min} / 1.73 \\
\mathrm{~m} 2\end{array}$ & $\begin{array}{l}39 \\
\mathrm{ml} / \mathrm{min} / 1.73 \\
\mathrm{~m} 2\end{array}$ \\
\hline 4 & $\begin{array}{l}\text { Mehrotra et } \\
\text { al. (2018) }\end{array}$ & Cohort & Low & $\begin{array}{l}\text { Triple therapy plus } \\
\text { IT }\end{array}$ & $\leq 47$ & $\leq 47$ & $\begin{array}{l}\text { With } \\
\text { more } \\
\text { male } \\
\text { patients }\end{array}$ & $\begin{array}{l}\text { With } \\
\text { more } \\
\text { male } \\
\text { patients }\end{array}$ & $\begin{array}{l}\text { Living } \\
\text { donors }\end{array}$ & $\begin{array}{l}69 \\
\mathrm{ml} / \mathrm{min} / 1.73 \\
\mathrm{~m} 2\end{array}$ & $\begin{array}{l}86 \\
\mathrm{ml} / \mathrm{min} / 1.73 \\
\mathrm{~m} 2\end{array}$ \\
\hline 5 & $\begin{array}{l}\text { Ma et al. } \\
(2012)\end{array}$ & $\begin{array}{l}\text { Cross- } \\
\text { section }\end{array}$ & High & Triple therapy & $>47$ & $>47$ & $\begin{array}{l}\text { With } \\
\text { fewer } \\
\text { male } \\
\text { patients }\end{array}$ & $\begin{array}{l}\text { With } \\
\text { fewer } \\
\text { male } \\
\text { patients }\end{array}$ & $\begin{array}{l}\text { Both } \\
\text { living } \\
\text { and } \\
\text { deceased } \\
\text { donors }\end{array}$ & $\begin{array}{l}54 \\
\mathrm{ml} / \mathrm{min} / 1.73 \\
\mathrm{~m} 2\end{array}$ & $\begin{array}{l}58 \\
\mathrm{ml} / \mathrm{min} / 1.73 \\
\mathrm{~m} 2\end{array}$ \\
\hline 6 & $\begin{array}{l}\text { Gregorini et } \\
\text { al. (2017) }\end{array}$ & Cohort & Low & Triple therapy & - & - & - & - & - & $\begin{array}{l}51 \\
\mathrm{ml} / \mathrm{min} / 1.73 \\
\mathrm{~m} 2\end{array}$ & $\begin{array}{l}49 \\
\mathrm{ml} / \mathrm{min} / 1.73 \\
\mathrm{~m} 2\end{array}$ \\
\hline 7 & $\begin{array}{l}\text { Kim et al. } \\
(2012)\end{array}$ & Cohort & High & Triple therapy & $\leq 47$ & $\leq 47$ & $\begin{array}{l}\text { With } \\
\text { fewer } \\
\text { male } \\
\text { patients }\end{array}$ & $\begin{array}{l}\text { With } \\
\text { more } \\
\text { male } \\
\text { patients }\end{array}$ & $\begin{array}{l}\text { Living } \\
\text { donors }\end{array}$ & $\begin{array}{l}58 \\
\mathrm{ml} / \mathrm{min} / 1.73 \\
\mathrm{~m} 2\end{array}$ & $\begin{array}{l}61 \\
\mathrm{ml} / \mathrm{min} / 1.73 \\
\mathrm{~m} 2\end{array}$ \\
\hline 8 & $\begin{array}{l}\text { Lee et al. } \\
(2011)\end{array}$ & $\begin{array}{l}\text { Cross- } \\
\text { section }\end{array}$ & Low & Triple therapy & $\leq 47$ & $>47$ & $\begin{array}{l}\text { With } \\
\text { fewer } \\
\text { male } \\
\text { patients }\end{array}$ & $\begin{array}{l}\text { With } \\
\text { fewer } \\
\text { male } \\
\text { patients }\end{array}$ & $\begin{array}{l}\text { Living } \\
\text { donors }\end{array}$ & $\begin{array}{l}54 \\
\mathrm{ml} / \mathrm{min} / 1.73 \\
\mathrm{~m} 2\end{array}$ & $\begin{array}{l}57 \\
\mathrm{ml} / \mathrm{min} / 1.73 \\
\mathrm{~m} 2\end{array}$ \\
\hline 9 & $\begin{array}{l}\text { Bienaimé et } \\
\text { al. (2013) }\end{array}$ & Cohort & High & $\begin{array}{l}\text { Triple therapy plus } \\
\text { IT }\end{array}$ & $>47$ & $>47$ & $\begin{array}{l}\text { With } \\
\text { fewer } \\
\text { male } \\
\text { patients }\end{array}$ & $\begin{array}{l}\text { With } \\
\text { fewer } \\
\text { male } \\
\text { patients }\end{array}$ & $\begin{array}{l}\text { Both } \\
\text { living } \\
\text { and } \\
\text { deceased } \\
\text { donors }\end{array}$ & $\begin{array}{l}57 \\
\mathrm{ml} / \mathrm{min} / 1.73 \\
\mathrm{~m} 2\end{array}$ & $\begin{array}{l}58 \\
\mathrm{ml} / \mathrm{min} / 1.73 \\
\mathrm{~m} 2\end{array}$ \\
\hline 10 & $\begin{array}{l}\text { Astor et al. } \\
(2019)\end{array}$ & Cohort & High & $\begin{array}{l}\text { Triple therapy plus } \\
\text { IT }\end{array}$ & $\leq 47$ & $>47$ & $\begin{array}{l}\text { With } \\
\text { more } \\
\text { male } \\
\text { patients }\end{array}$ & $\begin{array}{l}\text { With } \\
\text { fewer } \\
\text { male } \\
\text { patients }\end{array}$ & $\begin{array}{l}\text { Both } \\
\text { living } \\
\text { and } \\
\text { deceased } \\
\text { donors }\end{array}$ & - & - \\
\hline 11 & $\begin{array}{l}\text { Torres et al. } \\
(2016)\end{array}$ & $\begin{array}{l}\text { Cross- } \\
\text { section }\end{array}$ & Low & Triple therapy & - & - & - & - & - & - & - \\
\hline 12 & $\begin{array}{l}\text { Wissing et } \\
\text { al. (2005) }\end{array}$ & RCT & Low & $\begin{array}{l}\text { Triple therapy plus } \\
\text { IT }\end{array}$ & $\leq 47$ & $\leq 47$ & $\begin{array}{l}\text { With } \\
\text { fewer } \\
\text { male } \\
\text { patients }\end{array}$ & $\begin{array}{l}\text { With } \\
\text { fewer } \\
\text { male } \\
\text { patients }\end{array}$ & $\begin{array}{l}\text { Both } \\
\text { living } \\
\text { and } \\
\text { deceased } \\
\text { donors }\end{array}$ & - & - \\
\hline 13 & $\begin{array}{l}\text { Mehrotra et } \\
\text { al. (2020) }\end{array}$ & Cohort & Low & $\begin{array}{l}\text { Triple therapy plus } \\
\text { IT }\end{array}$ & $\leq 47$ & $\leq 47$ & $\begin{array}{l}\text { With } \\
\text { more } \\
\text { male } \\
\text { patients }\end{array}$ & $\begin{array}{l}\text { With } \\
\text { more } \\
\text { male } \\
\text { patients }\end{array}$ & - & - & - \\
\hline
\end{tabular}

Note. eGFR: estimated glomerular filtration rate; IT: induction therapy; RCT: randomized clinical trail

${ }^{1}$ in the VitD deficient group

${ }^{2}$ in the VitD sufficient group 


\begin{tabular}{|c|c|c|c|c|c|c|c|c|c|c|c|}
\hline ID & $\begin{array}{l}\text { Author } \\
\text { (Year) }\end{array}$ & $\begin{array}{l}\text { Study } \\
\text { type }\end{array}$ & $\begin{array}{l}\text { Study } \\
\text { quality }\end{array}$ & $\begin{array}{l}\text { Immunosuppressive } \\
\text { agents }\end{array}$ & $\mathrm{Age}^{1}$ & $\mathrm{Age}^{2}$ & Gender $^{1}$ & Gender $^{2}$ & $\begin{array}{l}\text { Donor } \\
\text { type }\end{array}$ & eGFR $^{1}$ & eGFR $^{2}$ \\
\hline 14 & $\begin{array}{l}\text { Obi et al. } \\
\text { (2013) }\end{array}$ & Cohort & Low & Triple therapy & - & - & - & - & - & - & - \\
\hline \multicolumn{12}{|c|}{ Note. eGFR: estimated glomerular filtration rate; IT: induction therapy; RCT: randomized clinical trail } \\
\hline \multicolumn{12}{|c|}{${ }^{1}$ in the VitD deficient group } \\
\hline 2 in & VitD suff & group & & & & & & & & & \\
\hline
\end{tabular}

\subsection{The Association Between VitD Deficiency and Acute Rejection}

Patients in the VitD-deficient group had an $82 \%$ increased chance of acute rejection compared with patients in the VitD-sufficient group, and this effect was significant (OR 1.82; 95\% confidence interval $\left.[\mathrm{Cl}][1.29,2.56] ; P^{2}=52.3 \%\right)$. Cl was narrow, which indicated that this result was conclusive and can be generalized to a larger population (Fig. 2).

\subsubsection{Publication Bias Assessment}

For the publication bias assessment, three methods were employed. As a first method, the funnel plot showed a homogeneous pattern and therefore non-considerable publication bias (Supplemental Fig. 1). As a second method, in line with the previous method, Begg's and egger's tests showed nonconsiderable publication bias as well ( $p=0.913$ and $p=0.744$, respectively). Egger's graph is shown in Supplemental Fig. 2 . Finally, as a third method, the trim and fill method added one paper to our studies; however, the added study did not affect the pooled effect size (Fig. 3 and Supplemental File 4).

\subsubsection{Subgroup Analyses}

As it was shown in Fig. 1, primary studies had different results. We performed some subgroup analyses to find potential sources of this statistical heterogeneity. Moreover, subgroup analyses let us analyze studies that are similar together on the aspect of at least one variable. The results of subgroup analyses are summarized in Table 2.

Table 2

The results of all subgroup analyses compared with total result.

\begin{tabular}{|c|c|c|c|c|c|}
\hline $\begin{array}{l}\text { Subgroup } \\
\text { variable }\end{array}$ & Category & Number of studies & Pooled effect size & $95 \% \mathrm{Cl}$ & $\left.\right|^{2}$ \\
\hline \multirow{2}{*}{$\begin{array}{l}\text { Study } \\
\text { quality }\end{array}$} & High & 6 & 2.16 & $1.21,3.87$ & $69.5 \%$ \\
\hline & Low & 8 & 1.41 & $1.04,1.90$ & $0.0 \%$ \\
\hline Induction therapy & IT & 7 & 1.78 & $1.00,3.16$ & $62.7 \%$ \\
\hline \multirow[t]{2}{*}{ Age in the deficient group } & $\leq 47$ years & 7 & 2.23 & $1.28,3.86$ & $27.7 \%$ \\
\hline & $>47$ years & 4 & 1.61 & $0.92,2.83$ & $44.1 \%$ \\
\hline \multirow[t]{2}{*}{ Age in the sufficient group } & $>47$ years & 6 & 1.75 & $1.04,2.96$ & $64.3 \%$ \\
\hline & $\leq 47$ years & 5 & 2.40 & $1.00,5.78$ & $37.2 \%$ \\
\hline \multirow[t]{2}{*}{ Gender in the deficient group } & With more male patients & 5 & 2.58 & $1.94,3.43$ & $0.0 \%$ \\
\hline & With fewer male patients & 6 & 1.68 & $0.91,3.09$ & $52.3 \%$ \\
\hline \multirow[t]{2}{*}{ Gender in the sufficient group } & With more male patients & 5 & 3.20 & $1.56,6.56$ & $5.0 \%$ \\
\hline & With fewer male patients & 6 & 1.58 & $0.94,2.65$ & $65.2 \%$ \\
\hline \multirow[t]{2}{*}{ Donor type in the deficient group } & Both deceased and living donors & 7 & 1.79 & $1.12,2.87$ & $57.7 \%$ \\
\hline & living donor & 3 & 3.60 & $0.81,16.11$ & $60.4 \%$ \\
\hline Total & & 14 & 1.82 & $1.29,2.56$ & $52.3 \%$ \\
\hline
\end{tabular}

Quality of Studies

Page 6/18 
High-quality studies were compared with low-quality ones. There were six studies in the high-quality subgroup and eight studies in the low-quality one. High-quality studies showed 2.16 -fold increased chance of acute rejection. The results of both high-quality $\left(O R 2.16 ; 95 \% \mathrm{Cl}[1.21,3.87] ; P^{2}=69.5 \%\right)$ and low-quality subgroups $\left(O R 1.41 ; 95 \% \mathrm{Cl}[1.04,1.90] ;{ }^{2}=0.0 \%\right)$ were significant and consistent with the overall result (Fig. 4).

\section{Induction Therapy}

There were seven studies in each subgroup. The results of both IT $\left(O R 1.78 ; 95 \% \mathrm{Cl}[1.00,3.16] ; P^{2}=62.7 \%\right)$ and non-IT subgroups $(O R 1.82 ; 95 \% \mathrm{Cl}$ $\left.[1.17,2.84] ; P^{2}=36.7 \%\right)$ were consistent with the overall result. The result in the IT subgroup was not significant (Supplemental Fig. 3). This subgroup did not affect the pooled effect size.

\section{Age: In the Deficient and Sufficient Groups}

Among 14 studies, 11 studies had age information of both deficient and sufficient groups separately. VitD-deficient patients $\leq 47$ years showed a 2.23 fold increased chance of acute rejection (OR 2.23; $95 \% \mathrm{Cl}[1.28,3.86] ;=27.7 \%$ ), which was significant. VitD-deficient patients $>47$ years showed a $61 \%$ increased chance of acute rejection (OR 1.61; $95 \% \mathrm{Cl}[0.92,2.83] ; R=44.1 \%)$, which was not significant (Fig. 5).

VitD-sufficient patients $\leq 47$ years showed a 2.40 -fold increased chance of acute rejection, which was not significant $(O R 2.40 ; 95 \% \mathrm{Cl}[1.00,5.78] ; \quad P=$ $37.2 \%)$. VitD-sufficient patients $>47$ years showed a $75 \%$ increased chance of acute rejection, which was significant $(O R 1.75 ; 95 \% \mathrm{Cl}[1.04,2.96] ;=$ 64.3\%) (Supplemental Fig. 4).

Gender

Among 14 studies, 11 studies had gender information of both deficient and sufficient groups separately. Studies with more male patients showed a 2.85 -fold increased chance of acute rejection, which was significant $\left(O R 2.85 ; 95 \% \mathrm{Cl}[1.31,6.18] ;{ }^{2}=12.7 \%\right)$. Studies with fewer male patients showed a $65 \%$ increased chance of acute rejection, which was not significant $(O R 1.65 ; 95 \% \mathrm{Cl}[0.97,2.79] ; 2=66.7 \%)($ Fig. 6$)$.

Moreover, studies with more male patients in the VitD-deficient group showed a 2.58-fold increased chance of acute rejection, which was significant (OR 2.58; 95\% CI [1.94, 3.43]; $R=0.0 \%$ ). Studies with fewer male patients in the VitD-deficient group showed a $68 \%$ increased chance of acute rejection, which was not significant (OR 1.68; $\left.95 \% \mathrm{Cl}[0.91,3.09] ; P^{2}=52.3 \%\right)$ (Supplemental Fig. 5).

Studies with more male patients in the VitD-sufficient group showed a 3.20-fold increased chance of acute rejection, which was significant (OR 3.20; $\left.95 \% \mathrm{Cl}[1.56,6.56] ; P^{2}=5.0 \%\right)$. Studies with fewer male patients in the VitD-sufficient group showed a $58 \%$ increased chance of acute rejection, which was not significant (OR 1.58; $95 \% \mathrm{Cl}[0.94,2.65]$; $\left.P^{2}=65.2 \%\right)$ (Supplemental Fig. 6).

Donor Type

Among 14 studies, 10 studies had donor type information. Studies with both living and deceased donors showed a $79 \%$ increased chance of acute rejection, which was significant $(O R 1.79 ; 95 \% \mathrm{Cl}[1.12,2.87] ;=57.7 \%)$. Studies with living donors showed a 3.60 -fold increased chance of acute rejection (OR3.60; 95\% $\left.\mathrm{Cl}[0.81,16.11] ;{ }^{2}=60.4 \%\right)$. However, this result was not significant and conclusive. (Supplemental Fig. 7).

\section{Meta-Regression Analysis}

Nine studies reported the rate of eGFR. We performed a meta-regression analysis on eGFR in each group separately. The eGFR of patients did not affect the pooled effect size. In other words, VitD deficiency independent from the eGFR of patients increased the chance of acute rejection (Fig. 7).

\section{Sensitivity Analysis}

Sensitivity analysis showed that if the studies are separately omitted, the pooled effect size does not change remarkably. Therefore, the pooled effect size had a robust result (Fig. 8 and Supplemental File 5).

\section{Discussion}

A total of 14 studies with 4,770 kidney transplant recipients were eligible to be included in this study. This is the first systematic review and metaanalysis study, which assesses the association between VitD concentration and the chance of acute rejection in kidney transplant recipients. The results of primary studies regarding the association between VitD and the chance of acute rejection were not conclusive. Some of them indicated that VitD deficiency is associated with acute rejection occurrence, but others not. These different statistical results may result from the distinct characteristics of studies' subjects. Thus, we performed different subgroup analyses to find the potential sources of statistical heterogeneity observed between primary studies.

In general, after the combination of all studies (14 studies and 4,770 patients), we showed that patients with VitD deficiency had an $82 \%$ increased chance of acute rejection. This result was not influenced by random errors, and, regarding the narrow $\mathrm{Cl}$, we can conclude that this result is conclusive and can be generalized to a larger population. Further, we indicated that several variables separately reduced the statistical heterogeneity (Table 2 ). For 
instance, study quality and gender of patients were the most important factors that reduced the heterogeneity. As an example, in the low-quality category, the heterogeneity was reduced from $52.3-0.0 \%$; further, in studies with more male patients, the heterogeneity was reduced from $52.3-0.0 \%$ and $5.0 \%$ in the deficient and sufficient groups, respectively.

The study quality and male gender also affected the pooled effect size. High-quality studies increased the chance of acute rejection from $O R 1.82$ to $O R 2.91$, while low-quality studies reduced the chance of acute rejection from $O R 1.82$ to $O R 1.41$. In other words, the association between VitD and the chance of acute rejection is higher in high-quality studies compared with low-quality ones. Thus, according to high quality studies, VitD-deficient patients had a 2.9-fold increased chance of acute rejection, which was a significant and conclusive result.

As mentioned above, another factor that affected the pooled effect size was the male gender. Studies with more male patients increased the pooled effect size from $O R 1.82$ to $O R 2.85$, which, regarding the $\mathrm{Cl}$, this result is inconclusive. On the other hand, studies with fewer male patients reduced it from OR 1.82 to $O R 1.65$.

Similar results were observed when VitD-deficient or -sufficient groups had more male patients (Table 2). The result of more-male-patients subgroup in the deficient group was significant and partially conclusive. However, the result of more-male-patients subgroup in the sufficient group was inconclusive. Consequently, it could be implied that male patients with VitD deficiency are more susceptible to acute rejection compared with female patients with VitD deficiency.

The age of patients was another factor that affected the pooled effect size. Patients with VitD deficiency $\leq 47$ years showed a $2.23-f o l d ~ i n c r e a s e d$ chance of acute rejection, which was significant and partially conclusive. Consequently, besides the male gender variable, patients with VitD deficiency $\leq 47$ years are more susceptible to acute rejection compared with patients with VitD deficiency $>47$ years.

Using meta-regression, we assessed the effect of eGFR on the pooled effect size. This analysis showed that patients with VitD deficiency independent from their eGFR had an increased chance of acute rejection.

After transplantation, the inflammatory reactions are initiated against the allograft. Because of danger signals and innate allorecognition, innate immunity is immediately activated against the allograft and thereby result in the activation of adaptive immunity. These inflammatory responses have a negative effect on the transplantation outcome and could be a reason for acute rejection (41-46). Given the anti-inflammatory role of VitD (which was stated in the Introduction section), VitD non-deficiency ( $\geq 20 \mathrm{ng} / \mathrm{ml}$ ) may modulate such inflammation and reduce the chance of acute rejection.

We acknowledge some limitations: (i) the results of this study are based on observational studies and thus definite conclusion on the clinical effect of VitD on acute rejection remains to be addressed using clinical trial studies; however, this study, for the first time, provided evidence-based results regarding the association between VitD and acute kidney rejection; (ii) several variables such as MHC mismatch, panel reactive antibodies, and cold ischemia time did not include in this study because there were not enough primary studies for reporting them.

\section{Conclusion}

In summary, the result of this systematic review and meta-analysis study indicated that patients with VitD deficiency had an increased chance of acute rejection. In addition, study quality and male gender were the main sources of statistical heterogeneity observed in the primary studies. Regarding the modulatory effect of VitD and also its role in reducing the chance of acute rejection, we suggest that clinicians keep the VitD status of their patients normal, before and after transplantation.

\section{Abbreviations}

VitD: Vitamin D; OR: odds ratio; Cl: confidence interval; eGFR: estimated glomerular filtration rate; DCs: dendritic cells; TH1: T helper 1; Tregs: regulatory T cells; IgG: immunoglobulin G; MHCII: major histocompatibility class Il; MOOS: Meta-analyses of Observational Studies; PRISMA: Preferred Reporting Items for Systematic Reviews and Meta-analyses; MESH: Medical Subject Headings; NOS: Newcastle-Ottawa Quality Assessment Scale; IT: induction therapy; RCT: randomized clinical trial;

\section{Declarations}

\section{Ethical Approval and Consent to participate}

Not applicable

\section{Consent for publication}

Not applicable

Availability of data and material 
The datasets analyzed in this article are not publicly available. Requests to access the datasets should be directed to the Mousa MohammadniaAfrouzi (m.mohammadnia@mubabol.ac.ir).

\section{Conflict interest statement}

The authors declare no conflict of interest.

\section{Funding}

Not applicable

\section{Authors' contributions}

M.M created a search syntax, wrote the manuscript, performed meta-analysis, and screening processes. S.M performed screening and selection processes. S.H performed screening and selection processes. S.A performed screening and data extraction processes. N.G performed screening and data extraction processes. M.S wrote the manuscript and performed quality analysis processes. M.MA wrote the manuscript, performed quality analysis processes, and reviewed the final version of the manuscript. All authors have read and approved the manuscript.

\section{Acknowledgments}

Not applicable

\section{References}

1. Gois PHF, Ferreira D, Olenski S, Seguro AC. Vitamin D and infectious diseases: simple bystander or contributing factor? Nutrients. $2017 ; 9(7): 651$.

2. Mahmoudi M, Rezaei N. Nutrition and Immunity: Springer; 2019.

3. Charoenngam N, Holick MF. Immunologic effects of vitamin D on human health and disease. Nutrients. 2020;12(7):2097.

4. Gil A, Plaza-Diaz J, Mesa MD. Vitamin D: classic and novel actions. Annals of Nutrition and Metabolism. 2018;72(2):87-95.

5. Holick MF. Vitamin D deficiency. The New England journal of medicine. 2007;357(3):266-81.

6. Mora JR, Iwata M, Von Andrian UH. Vitamin effects on the immune system: vitamins A and D take centre stage. Nature Reviews Immunology. 2008;8(9):685-98.

7. Aranow C. Vitamin D and the immune system. Journal of investigative medicine. 2011;59(6):881-6.

8. Lemire JM, Archer DC, Beck L, Spiegelberg HL. Immunosuppressive actions of 1, 25-dihydroxyvitamin D3: preferential inhibition of Th1 functions. The Journal of nutrition. 1995;125(suppl_6):1704S-8S.

9. Boonstra A, Barrat FJ, Crain C, Heath VL, Savelkoul HF, O'Garra A. 1a, 25-Dihydroxyvitamin D3 has a direct effect on naive CD4+ T cells to enhance the development of Th2 cells. The Journal of Immunology. 2001;167(9):4974-80.

10. Tang J, Zhou R, Luger D, Zhu W, Silver PB, Grajewski RS, et al. Calcitriol suppresses antiretinal autoimmunity through inhibitory effects on the Th17 effector response. The Journal of Immunology. 2009;182(8):4624-32.

11. MOCANU V, Oboroceanu T, Zugun-Eloae F. Current status in vitamin D and regulatory T cells-immunological implications. The Medical-Surgical Journal. 2013;117(4):965-73.

12. Piemonti L, Monti P, Sironi M, Fraticelli P, Leone BE, Dal Cin E, et al. Vitamin D3 affects differentiation, maturation, and function of human monocyte-derived dendritic cells. The Journal of Immunology. 2000;164(9):4443-51.

13. Széles L, Keresztes G, Töröcsik D, Balajthy Z, Krenács L, Póliska S, et al. 1, 25-dihydroxyvitamin D3 is an autonomous regulator of the transcriptional changes leading to a tolerogenic dendritic cell phenotype. The Journal of Immunology. 2009;182(4):2074-83.

14. Holick MF. Vitamin D status: measurement, interpretation, and clinical application. Annals of epidemiology. 2009;19(2):73-8.

15. Pincikova T, Paquin-Proulx D, Sandberg J, Flodström-Tullberg M, Hjelte L. Vitamin D treatment modulates immune activation in cystic fibrosis. Clinical \& Experimental Immunology. 2017;189(3):359-71.

16. Bouillon R. Vitamin D and cardiovascular disorders. Osteoporosis International. 2019:1-15.

17. Kulling PM, Olson KC, Olson TL, Feith DJ, Loughran Jr TP. Vitamin D in hematological disorders and malignancies. European journal of haematology. 2017;98(3):187-97.

18. Lee JR, Dadhania D, August P, Lee JB, Suthanthiran M, Muthukumar T. Circulating levels of 25-hydroxyvitamin D and acute cellular rejection in kidney allograft recipients. Transplantation. 2014;98(3):292.

19. Mehrotra S, Sharma RK, Gupta A, Prasad N, Bhadauria DS, Kaul A, et al. Low $25(\mathrm{OH})$ Vitamin-D levels are associated with inferior graft function in living related kidney transplant recipients. Journal of Renal Injury Prevention. 2018;7(4):224-9.

20. Lee D, Kong J, Cho K, Chan L, editors. Impact of vitamin D on proteinuria, insulin resistance, and cardiovascular parameters in kidney transplant recipients. Transplantation proceedings; 2011: Elsevier. 
21. Bienaimé F, Girard D, Anglicheau D, Canaud G, Souberbielle JC, Kreis H, et al. Vitamin D status and outcomes after renal transplantation. Journal of the American Society of Nephrology. 2013;24(5):831-41.

22. Park Y-J, Kim S-U, Lee K-H, Lee J-H, Kwon E, Jung H-Y, et al. Vitamin D deficiency is associated with increased risk of bacterial infections after kidney transplantation. The Korean journal of internal medicine. 2017;32(3):505.

23. Stroup DF, Berlin JA, Morton SC, Olkin I, Williamson GD, Rennie D, et al. Meta-analysis of observational studies in epidemiology: a proposal for reporting. Jama. 2000;283(15):2008-12.

24. Moher D, Liberati A, Tetzlaff J, Altman DG, Group P. Preferred reporting items for systematic reviews and meta-analyses: the PRISMA statement. PLoS med. 2009;6(7):e1000097.

25. Stang A. Critical evaluation of the Newcastle-Ottawa scale for the assessment of the quality of nonrandomized studies in meta-analyses. European journal of epidemiology. 2010;25(9):603-5.

26. Higgins JP, Altman DG, Gøtzsche PC, Jüni P, Moher D, Oxman AD, et al. The Cochrane Collaboration's tool for assessing risk of bias in randomised trials. Bmj. 2011;343:d5928.

27. Nikolakopoulou A, Mavridis D, Salanti G. How to interpret meta-analysis models: fixed effect and random effects meta-analyses. Evidence-based mental health. 2014;17(2):64-

28. Higgins JP, Thompson SG, Deeks JJ, Altman DG. Measuring inconsistency in meta-analyses. Bmj. 2003;327(7414):557-60.

29. Begg CB, Mazumdar M. Operating characteristics of a rank correlation test for publication bias. Biometrics. 1994:1088-101.

30. Egger M, Smith GD, Schneider M, Minder C. Bias in meta-analysis detected by a simple, graphical test. Bmj. 1997;315(7109):629-34.

31. Duval S, Tweedie R. Trim and fill: a simple funnel-plot-based method of testing and adjusting for publication bias in meta-analysis. Biometrics. 2000;56(2):455-63.

32. Kulshrestha S, Ojo AO, Luan FL. Metabolic syndrome, vitamin D deficiency and hypoadiponectinemia among nondiabetic patients early after kidney transplantation. American journal of nephrology. 2013;37(5):399-404.

33. Ma MK, Mok MM, Yung S, Tang CS, Chan TM. High prevalence of vitamin D insufficiency in southern Chinese renal transplant recipients. Renal failure. 2012;34(8):980-4.

34. Gregorini M, Sileno G, Pattonieri E, Corradetti V, Abelli M, Ticozzelli E, et al., editors. Understanding bone damage after kidney transplantation: a retrospective monocentric cross sectional analysis. Transplantation Proceedings; 2017: Elsevier.

35. Kim H, Kang S-W, Yoo T-H, Kim MS, Kim SI, Kim YS, et al. The impact of pretransplant 25-hydroxy vitamin D deficiency on subsequent graft function: an observational study. BMC nephrology. 2012;13(1):22.

36. Torres A, Torregrosa V, Marcen R, Campistol JM, Arias M, Hernández D, et al. Mineral metabolism disorders, vertebral fractures and aortic calcifications in stable kidney transplant recipients: The role of gender (EMITRAL study). Nefrología (English Edition). 2016;36(3):255-67.

37. Astor BC, Djamali A, Mandelbrot DA, Parajuli S, Melamed ML. The Association of 25-Hydroxyvitamin D Levels with Late Cytomegalovirus Infection in Kidney Transplant Recipients: the Wisconsin Allograft Recipient Database. Transplantation. 2019;103(8):1683-8.

38. Wissing KM, Broeders N, Moreno-Reyes R, Gervy C, Stallenberg B, Abramowicz D. A controlled study of vitamin D3 to prevent bone loss in renaltransplant patients receiving low doses of steroids. Transplantation. 2005;79(1):108-15.

39. Mehrotra S, Sharma RK, Mayya M. Vitamin D receptor activity, vitamin D status, and development of de-novo donor-specific antibody after renal transplantation. Indian Journal of Nephrology. 2020;30(2):72.

40. Obi Y, Hamano T, Ichimaru N, Tomida K, Matsui I, Fujii N, et al. Vitamin D deficiency predicts decline in kidney allograft function: a prospective cohort study. The Journal of Clinical Endocrinology \& Metabolism. 2014;99(2):527-35.

41. Ochando J, Ordikhani F, Boros P, Jordan S. The innate immune response to allotransplants: mechanisms and therapeutic potentials. Cellular \& molecular immunology. 2019;16(4):350-6.

42. Braza F, Brouard S, Chadban S, Goldstein DR. Role of TLRs and DAMPs in allograft inflammation and transplant outcomes. Nature Reviews Nephrology. 2016;12(5):281.

43. Oberbarnscheidt MH, Zeng Q, Li Q, Dai H, Williams AL, Shlomchik WD, et al. Non-self recognition by monocytes initiates allograft rejection. The Journal of clinical investigation. 2014;124(8):3579-89.

44. Chu Z, Sun C, Sun L, Feng C, Yang F, Xu Y, et al. Primed macrophages directly and specifically reject allografts. Cellular \& Molecular Immunology. 2020;17(3):237-46.

45. Zhao D, Abou-Daya KI, Dai H, Oberbarnscheidt MH, Li XC, Lakkis FG. Innate Allorecognition and Memory in Transplantation. Frontiers in immunology. 2020;11.

46. Mirzakhani M, Shahbazi M, Oliaei F, Mohammadnia-Afrouzi M. Immunological biomarkers of tolerance in human kidney transplantation: An updated literature review. Journal of cellular physiology. 2019;234(5):5762-74.

\section{Figures}




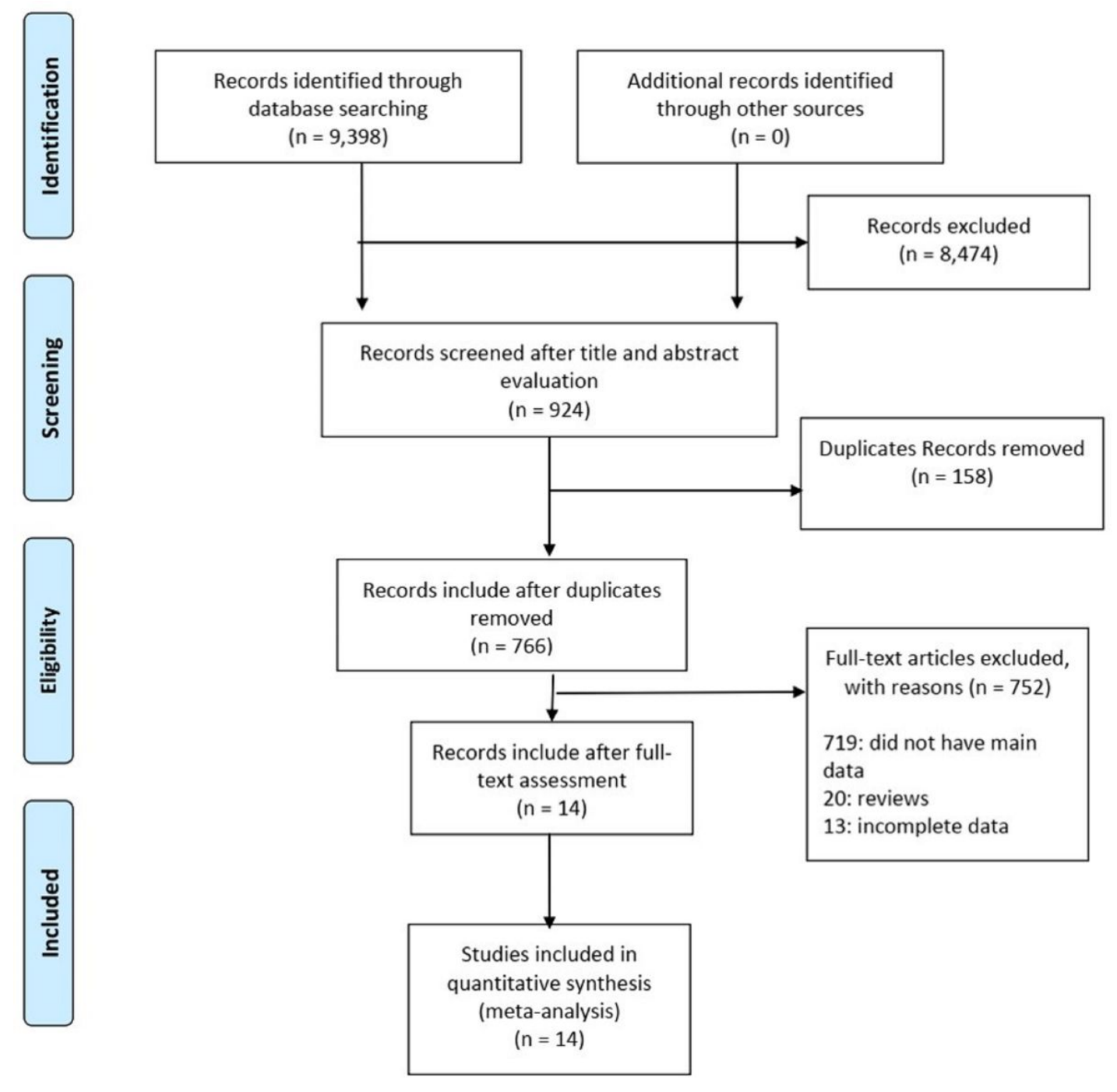

Figure 1

PRISMA flow chart of study identification Note. PRISMA: Preferred Reporting Items for Systematic Reviews and Meta-analyses 


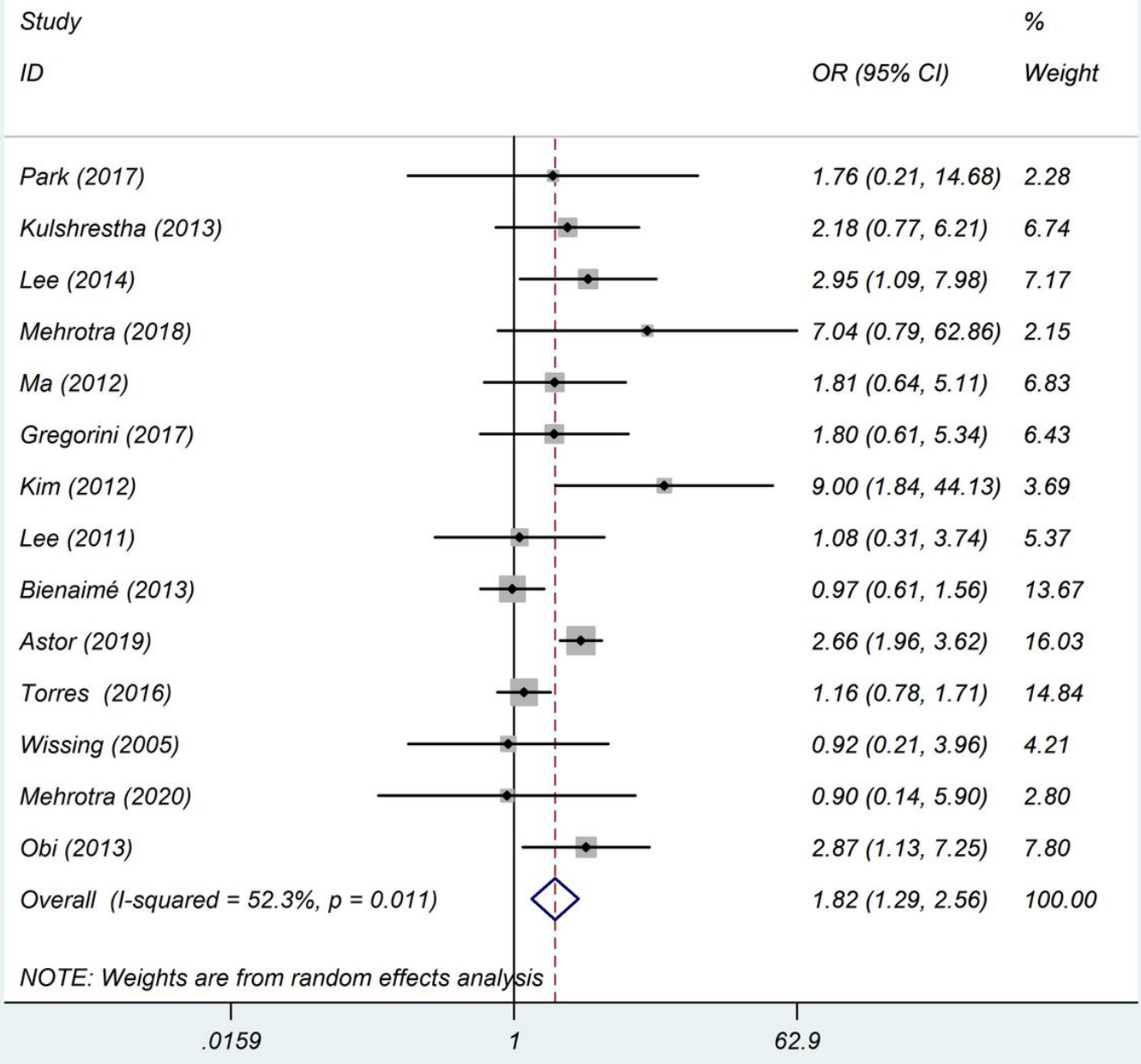

\section{Figure 2}

The forest plot of the association between VitD deficiency and acute rejection Note. VitD: vitamin D 


\section{Filled funnel plot with pseudo 95\% confidence limits}

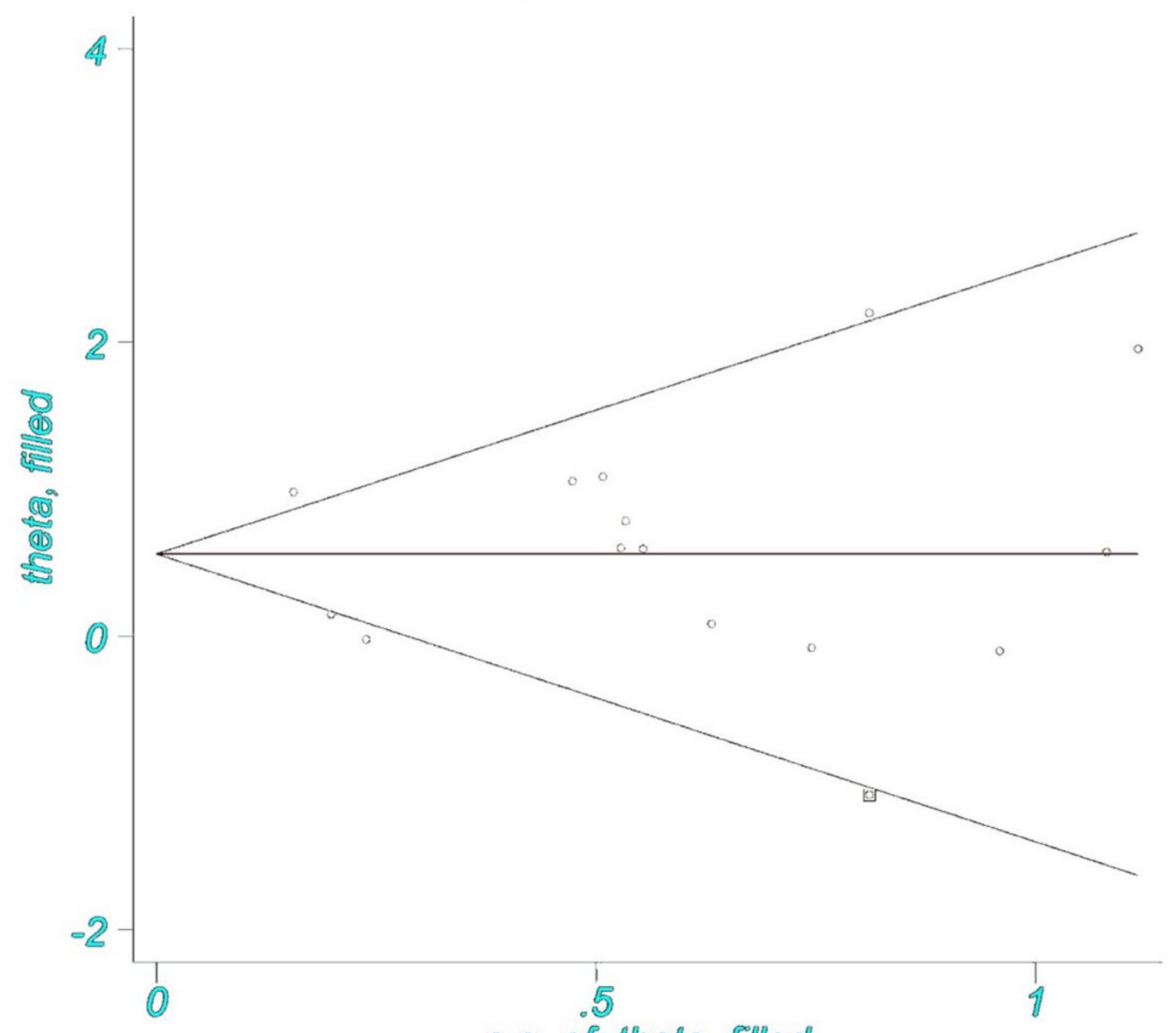

S.e. Off: thete, fillled

\section{Figure 3}

The funnel plot of publication bias assessment showed one added study. 


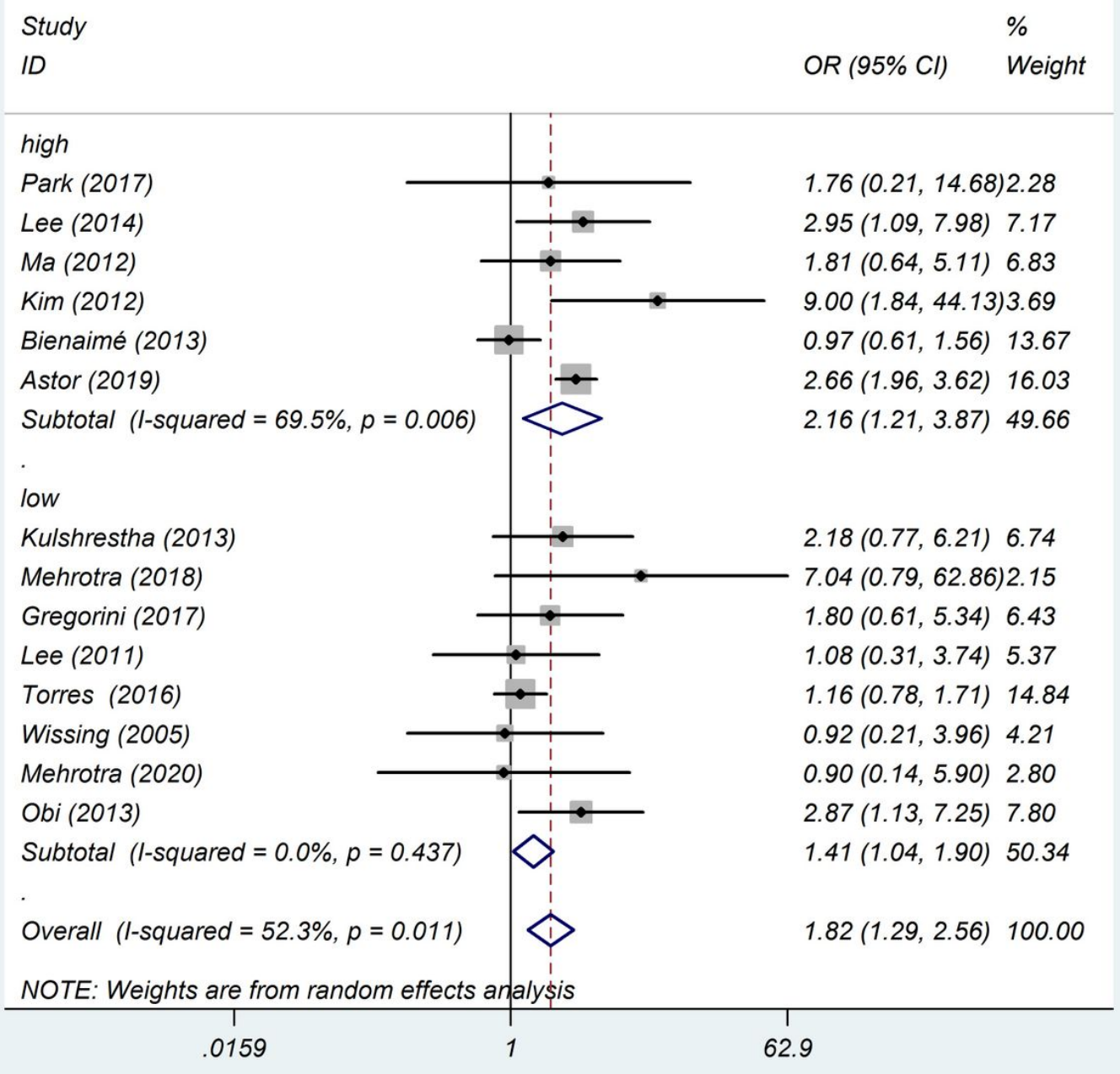

\section{Figure 4}

The subgroup analysis according to the quality of studies 
Study

$I D$

OR $(95 \% \mathrm{Cl})$

Weight

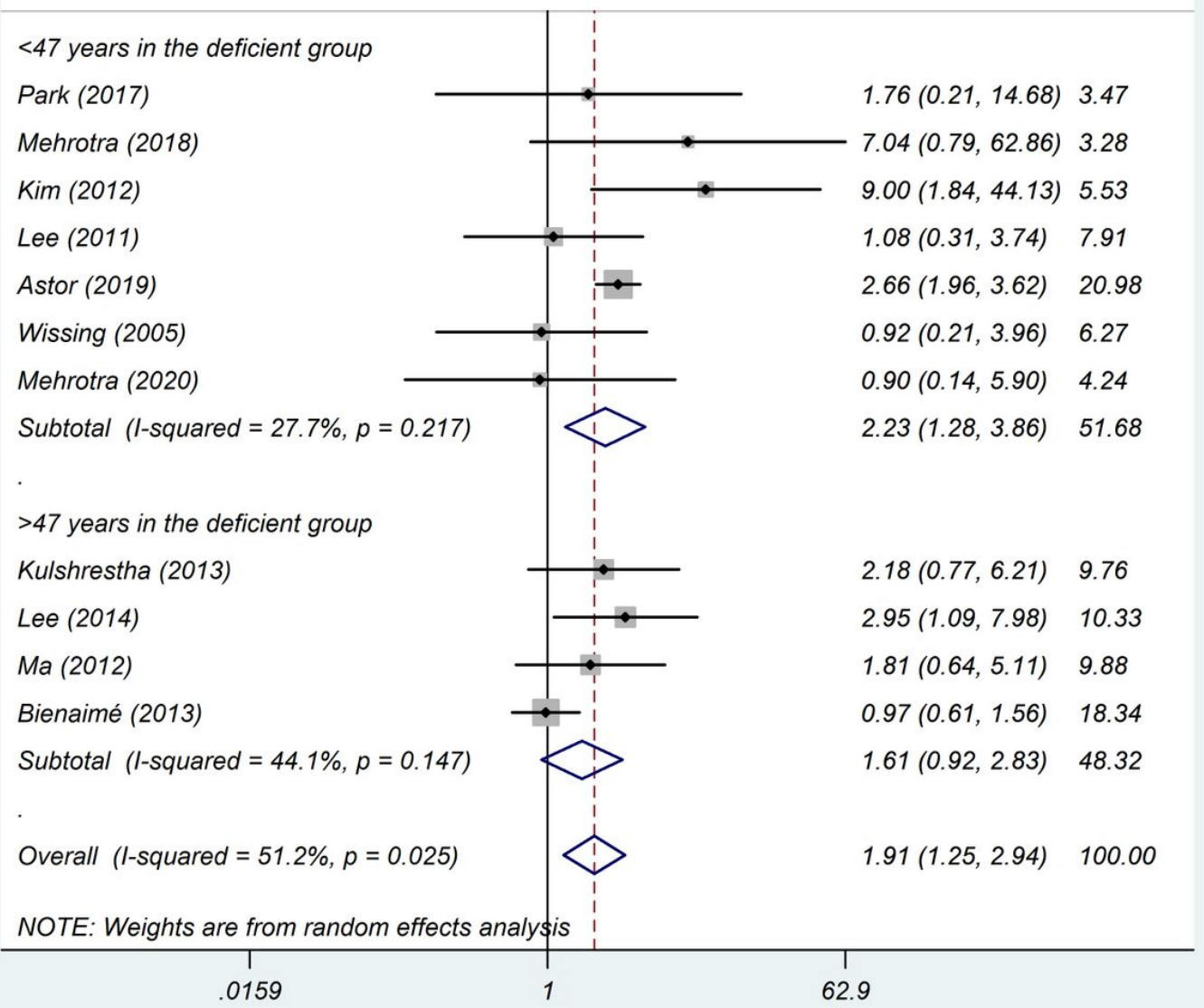

\section{Figure 5}

The subgroup analysis according to the age of VitD-deficient patients 
Study

ID

OR $(95 \% C l)$

Weight

With more male patients

Park (2017)

Kulshrestha (2013)

Mehrotra (2018)

Kim (2012)

Mehrotra (2020)

Subtotal (I-squared $=12.7 \%, p=0.333$ )

With fewer male patients

Lee (2014)

Ma (2012)

Lee (2011)

Bienaimé (2013)

Astor (2019)

Wissing (2005)

Subtotal $(I$-squared $=66.7 \%, p=0.010)$

.

Overall $(I$-squared $=51.2 \%, p=0.025)$

NOTE: Weights are from random effects analysis

$1.76(0.21,14.68) 3.47$

$2.18(0.77,6.21) \quad 9.76$

$7.04(0.79,62.86) 3.28$

$9.00(1.84,44.13) 5.53$

$0.90(0.14,5.90) \quad 4.24$

$2.85(1.31,6.18) \quad 26.29$

$2.95(1.09,7.98) \quad 10.33$

$1.81(0.64,5.11) \quad 9.88$

$1.08(0.31,3.74) \quad 7.91$

$0.97(0.61,1.56) \quad 18.34$

$2.66(1.96,3.62) \quad 20.98$

$0.92(0.21,3.96) \quad 6.27$

$1.65(0.97,2.79) \quad 73.71$

$1.91(1.25,2.94) \quad 100.00$

\section{Figure 6}

The subgroup analysis according to the gender of patients 


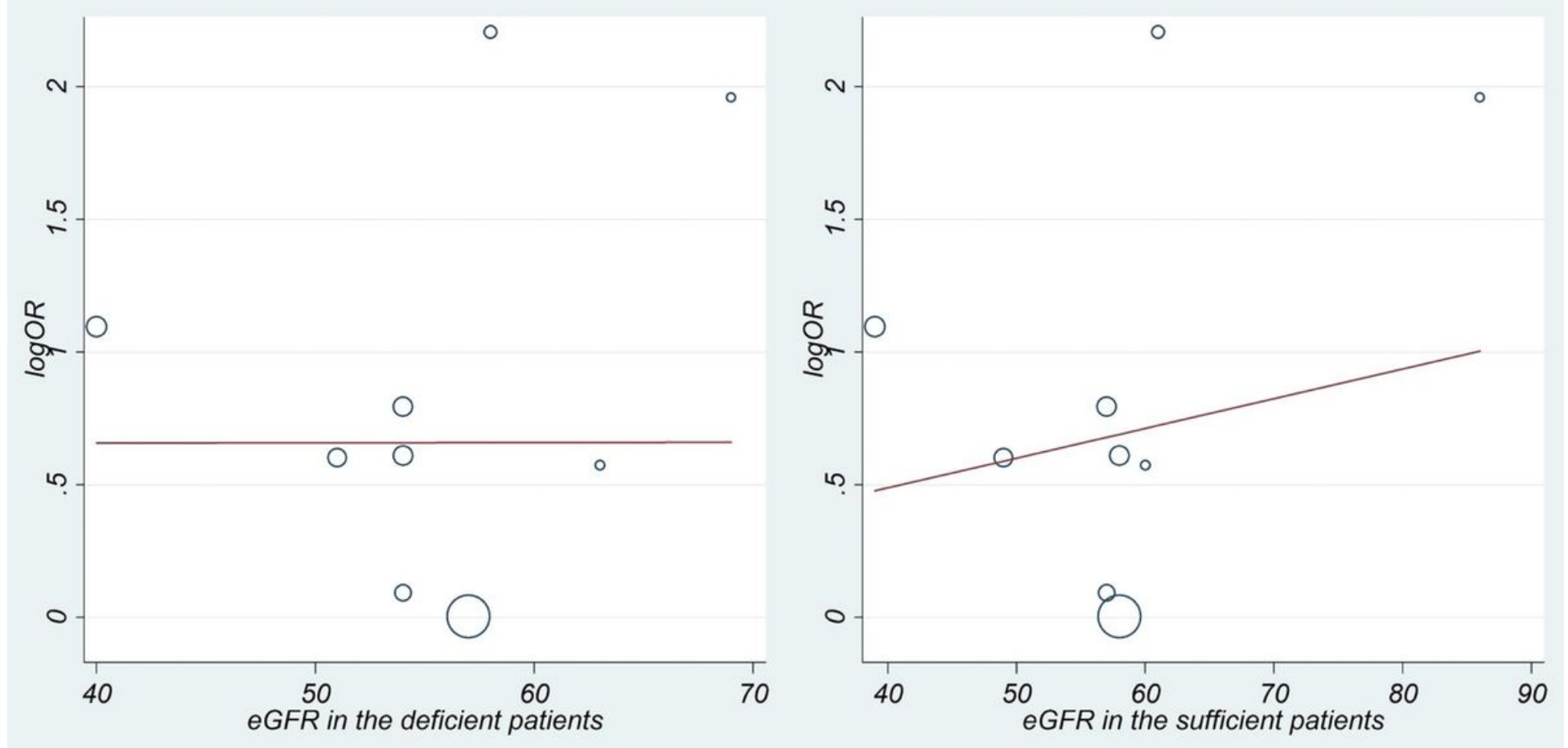

Figure 7

The meta-regression analysis according to the eGFR of VitD-deficient or -sufficient patients 


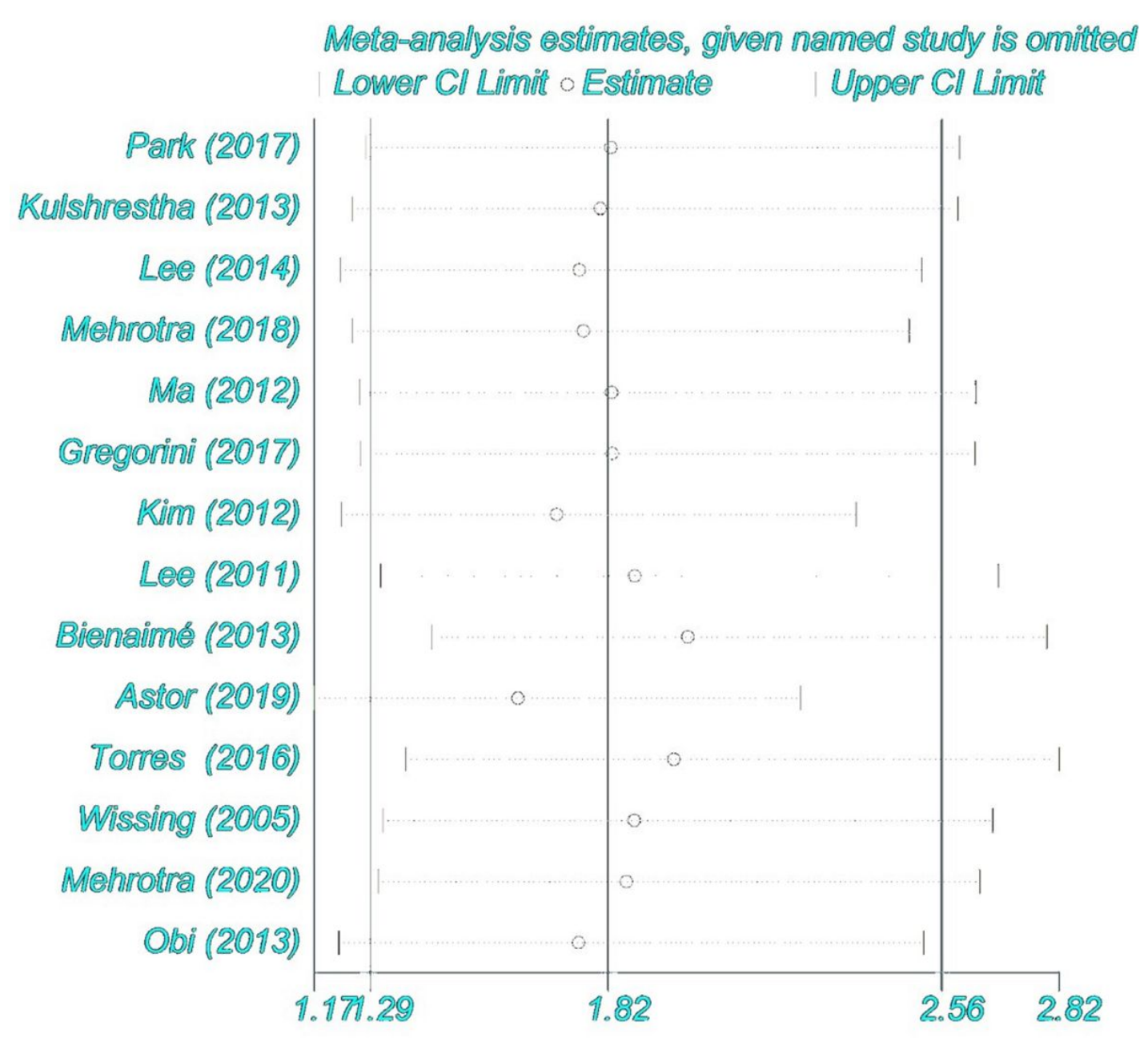

\section{Figure 8}

The sensitivity analysis showed that no different result is exist after omitting each study separately

\section{Supplementary Files}

This is a list of supplementary files associated with this preprint. Click to download.

- SupplementalFigures.pdf

- Supplementalfile1.1.PRISMA2009ChecklistMSWord.pdf

- supplementaryfile1.Searchsyntax..pdf

- supplementaryfile2.NEWCASTLEcrosssection..pdf

- supplementaryfile2.NewcastleCohort..pdf

- supplementaryfile3.qualityanalysis.pdf

- supplementaryfile4.trimandfill.pdf

- supplementaryfile5.pdf 